\title{
Najnowsze zmiany ustawy o postępowaniu egzekucyjnym w administracji
}

\section{Wprowadzenie}

Asumptem dla prawodawcy do dokonania zmian w Ustawie z dnia 17 czerwca 1966 r. o postępowaniu egzekucyjnym w administracji ${ }^{1}$ była uchwalona w dniu 10 lipca 2015 r. ustawa o administracji podatkowej². Założeniem leżącym u podstaw wprowadzenia tego nowego aktu prawnego była konieczność dokonania rewizji istniejącego stanu prawnego dotyczącego celów, zadań oraz struktury ${ }^{3}$ organów administracji podatkowej, wyrażonego w przepisach Ustawy z dnia 21 czerwca 1996 r. o urzędach i izbach skarbowych ${ }^{4}$. Do wprowadzenia ustawy przyczyniło się również Zalecenie Rady Unii Europejskiej z dnia 2 czerwca 2014 r. w sprawie krajowego programu reform Polski na 2014 r., zawierające opinię Rady na temat przedstawionego przez Polskę programu konwergencji na 2014 r. (COM(2014)422), gdzie zarekomendowano Polsce usprawnienie skuteczności administracji podatkowej. Pierwotnie ustawa o administracji podatkowej miała wejść w życie z dniem 1 stycznia 2016 r. (art. 77 pkt 1, z wyłączeniem przepisów, które weszły w życie z dniem 1 września 2015 r. - art. 77 pkt 2 i przepisów wchodzących w życie z dniem 1 września 2015 r. - art. 77 pkt 3), jednak

${ }^{1}$ Tekst jedn. Dz.U. 2014, poz. 1619 ze zm., dalej „ustawa egzekucyjna”.

2 Dz.U. poz. 2015 ze zm., dalej „ustawa o administracji podatkowej”.

${ }^{3}$ Druk sejmowy nr 3320/VII kadencja z dnia 10 IV 2015 r., cz. 1, http://www.sejm. gov.pl/sejm7.nsf/druk.xsp?documentId=77CF28B244C1938DC1257E26003F1748 (dostęp: 8 III 2016).

${ }^{4}$ Tekst jedn. Dz.U. 2015, poz. 578 ze zm.

${ }^{5}$ Druk sejmowy nr 3320/VII kadencja. 
zmiany polityczne, jakie dokonały się w naszym kraju na skutek wyborów parlamentarnych z 2015 r., sprawily, iż Ustawą z dnia 16 grudnia 2015 r. o zmianie ustawy o administracji podatkowej oraz zmianie ustawy - Ordynacja podatkowa oraz niektórych innych ustaw ${ }^{6}$ (art. 1 ust. 2 lit. a) okres vacatio legis został przesunięty do dnia 1 lipca 2016 r. ${ }^{7}$ $\mathrm{W}$ uzasadnieniu projektu ustawy ${ }^{8}$ podniesiono, że przedłużenie okresu spoczywania ustawy wynika z konieczności właściwego przygotowania jednostek administracji podatkowej do sprawnego realizowania zadań w zakresie planowanych szerokich zmian organizacyjnych. Wydłużone vacatio legis nie objęło jednak swym zastosowaniem znaczącej części art. 39 ustawy o administracji podatkowej i sprawiło, że najbardziej doniosłe zmiany $\mathrm{w}$ ustawie o postępowaniu egzekucyjnym $\mathrm{w}$ administracji weszły w życie $\mathrm{z}$ dniem 1 stycznia $2016 \mathrm{r}$.

Celem niniejszego opracowania jest dokonanie analizy zmian w ustawie egzekucyjnej wprowadzonych na mocy ustawy o administracji podatkowej. Najnowsze zmiany w ustawie egzekucyjnej charakteryzują się jednak nie mniejszą doniosłością ${ }^{9}$ niż te przeprowadzone nowelizacją z dnia 11 października 2013 r. i wprowadzające w życie ustawę o wzajemnej pomocy przy dochodzeniu podatków, należności celnych i innych należności pieniężnych ${ }^{10}$. Modyfikacje poczynione przez ustawodawcę nie są tylko zmianami redakcyjnymi czy ujednolicającymi terminologię funkcjonującą $\mathrm{w}$ systemie prawnym ${ }^{11}$, ale w sposób dotąd nieznany ustawie egzekucyjnej kształtują stosunki procesowe przez ten akt prawny regulowane.

${ }^{6}$ Dz.U. poz. 2184 r., dalej „ustawa o zmianie ustawy o administracji podatkowej”.

${ }^{7}$ Działanie to jest związane z pracami legislacyjnymi, jakie Ministerstwo Finansów prowadzi nad nieopublikowanym jeszcze projektem ustawy o Krajowej Administracji Skarbowej, która w sposób zasadniczy zmienić ma model organizacyjny organów administracji skarbowej, administracji celnej oraz kontroli skarbowej. Na dzień sporządzenia niniejszego opracowania projekt ustawy nie został jeszcze oficjalnie upubliczniony przez resort finansów, jednak jego przedruk został rozesłany do dyrektorów izb skarbowych, izb celnych oraz urzędów kontroli skarbowej w celu zaopiniowania. Tekst projektu dostępny na http://www.skarbowcy.pl/blaster/extarticle.php?show=article\&article_ id=24324 (dostęp: 10 III 2016).

${ }^{8}$ Druk sejmowy nr 76/VIII kadencja z dnia 3 XII 2015 r., http://www.sejm.gov. pl/Sejm8.nsf/PrzebiegProc.xsp?id=2FCBDF906BC87F93C1257F160023F97A (dostęp: 10 III 2016).

${ }^{9}$ P. Ostojski, W. Piątek, Egzekucja administracyjna świadczeń pieniężnych, Wrocław 2014, s. 13.

${ }^{10}$ Dz.U. poz. 1289 ze zm., dalej „ustawa o wzajemnej pomocy”.

${ }^{11}$ Jak np. zmiany wyrażone w art. 39 pkt 1, 19, 20, 21 i 24 ustawy o administracji podatkowej (oczekujące na wejście w życie na mocy art. 1 pkt 2 lit. a ustawy o zmianie 


\section{Odstępstwa od zasady prawnego obowiązku prowadzenia egzekucji}

Obowiązująca ustawa egzekucyjna czyni przedmiotem swej regulacji (oprócz kwestii związanych z prowadzeniem przez organy egzekucyjne postępowania i stosowania przez te podmioty środków przymusu) sposób postępowania wierzycieli w przypadku uchylania się przez zobowiązanych od wykonania ciążących na nich obowiązków ${ }^{12}$. Wierzyciele obowiązków poddanych egzekucji administracyjnej do czasu wejścia $\mathrm{w}$ życie zmian opisywanych $\mathrm{w}$ niniejszym opracowaniu ${ }^{13}$ zobligowani byli do pełnej realizacji zasady prawnego obowiązku prowadzenia egzekucji ${ }^{14}$. Oznacza to, że w przeciwieństwie do wierzycieli należności cywilnoprawnych podmioty upoważnione do dochodzenia należności wyrażonych w art. 2 ustawy egzekucyjnej nie były uprawnione do rozporządzania obowiązkiem stanowiącym przedmiot egzekucji.

Odnosząc się do meritum zmian wprowadzonych przez ustawodawcę, należy wskazać na dyspozycje wyrażone w art. $6 \S 1 \mathrm{~b}-1 \mathrm{~d}$ ustawy egzekucyjnej. Zmiany te wprawdzie nie upoważniają wierzycieli do rozporządzania swoim uprawnieniem $\mathrm{w}$ zakresie przenoszenia praw na inne podmioty ${ }^{15}$, jednak dopuszczają do sytuacji odstąpienia przez wierzyciela od podjęcia czynności zmierzających do zastosowania środków egzekucyjnych, czyniąc tym samym wyjątek od zasady prawnego obowiązku prowadzenia egzekucji administracyjnej. Pierwsza ze zmian wyrażona w art. $6 \S 1 \mathrm{~b}$ przejawia się w udzieleniu wierzycielowi kompetencji do podejmowania wobec zobowiązanego działań informacyjnych,

ustawy o administracji podatkowej), które ujednolicają terminologię ustawy egzekucyjnej w zakresie nazewnictwa ograniczonych praw rzeczowych mających swoje źródło w ustawie z dnia 15 XII 2000 r. o spółdzielniach mieszkaniowych (tekst jedn. Dz.U. 2013, poz. 1222 ze zm.). Na marginesie stwierdzić należy, iż przedłużenie vacatio legis wskazanych przepisów nie znajduje żadnego racjonalnego uzasadnienia, zwłaszcza że ujednolicona terminologia obowiązuje już od 20 II 2005 r.

12 Postępowanie administracyjne - ogólne, podatkowe, egzekucyjne i przed sadami administracyjnymi, pod red. M. Wierzbowskiego, Warszawa 2013, s. 338.

${ }^{13}$ Wprowadzonych ustawą o administracji podatkowej.

${ }^{14} \mathrm{~J}$. Wyporska-Frankiewicz, Zasady ogólne postępowania egzekucyjnego, w: Doradca podatkowy w egzekucji administracyjnej obowiązków pieniężnych, pod red. J.P. Tarny, Warszawa 2012, s. 66.

${ }^{15}$ Za wciąż aktualny należy uznać pogląd wyrażony w uchwale Sądu Najwyższego (SN) z 26 XI 2003 r., sygn. III CZP 84/03, Orzecznictwo Sądu Najwyższego, Izba Cywilna, http://www.sn.pl/orzecznictwo/SitePages/Baza_orzeczen.aspx?ItemID=8032\&ListName=Orzeczenia1 \&Sygnatura=III+CZP+84\%2f03 (dostęp: 14 III 2016). 
których celem jest dobrowolne wykonanie obowiązku. Wyrażone w $\S 4$ ust. 2 Rozporządzenia Ministra Finansów w sprawie trybu postępowania wierzycieli należności pieniężnych z dnia 30 grudnia 2015 r. ${ }^{16}$ działania informacyjne to wszelkie zastosowane czynności, które przybrać moga formę pisemną, dźwiękową lub graficzną i których celem jest przekonanie zobowiązanego do dobrowolnego wykonania ciążącego na nim obowiązku o charakterze pieniężnym. Do pełnego zdekodowania normy prawnej wyrażającej wskazaną kompetencję wierzyciela niezbędne jest uwzględnienie przepisów Rozporządzenia Ministra Finansów z dnia 30 grudnia 2015 r. w sprawie trybu postępowania wierzycieli należności pieniężnych wydanego na podstawie art. $6 \S 2$ ustawy egzekucyjnej. Analiza $\S 7$ przedmiotowego rozporządzenia wykazuje, że podjęcie działań informacyjnych może zastępować przedsięwzięcie czynności zmierzających do zastosowania środków egzekucyjnych tylko w sytuacji, jeżeli należność pieniężna wraz z odsetkami nie przekracza kwoty $116 \mathrm{zt}^{17}$. W tych przypadkach zastosowanie czynności informacyjnych uprawnia wierzyciela do odstąpienia od wystawienia upomnienia przez maksymalnie 21 dni od momentu podjęcia tych działań.

Omawianą zmianę można uznać za zasadna, gdyż wprowadza ona do procedury funkcjonowania wierzycieli należności publicznoprawnych element proporcjonalności. Ustawodawca słusznie dostrzegł, że w przypadkach drobnych zaległości (tj. do 116 zł) wskazane jest przekonanie zobowiązanego do dobrowolnego wykonania obowiązku. W tego typu przypadkach z jednej strony zbędne jest angażowanie całego aparatu przymusu państwowego, z drugiej zaś bezwzględne wystawienie upomnienia oraz wszczynanie egzekucji generuje opłaty, które stanowić mogą znaczną część niewykonanego pierwotnie obowiązku.

Druga zmiana wyrażona w art. 6 § 1c-1d ustawy egzekucyjnej dotyczy przypadków inicjowania przez wierzyciela kolejnych postępowań egzekucyjnych, w sytuacji gdy poprzednie postępowania prowadzone na jego rzecz zostały umorzone ze względu na bezskuteczność egzekucji. W zmienionym stanie prawnym wierzyciel jest uprawniony do odstąpienia od podjęcia czynności zmierzających do zastosowania środków egzekucyjnych w przypadku, gdy postępowania prowadzone

${ }^{16}$ Dz.U. poz. 2367.

${ }^{17}$ Co stanowi dziesięciokrotność kosztów upomnienia, którego podstawowa stawka na podstawie § 1 Rozporządzenia Ministra Finansów z dnia 11 IX 2015 r. w sprawie wysokości kosztów upomnienia skierowanego przez wierzyciela do zobowiązanego przed wszczęciem egzekucji administracyjnej (Dz.U. poz. 1526) wynosi 11,60 zł. 
w stosunku do innych jego należności zostały umorzone w wyniku bezskuteczności egzekucji. Przesłanki do skorzystania z wprowadzonej instytucji zostały wyrażone w art. 6 § 1c ustawy egzekucyjnej. Ustawodawca przewidział, że maksymalny okres wstrzymania działań wierzycielskich wynosić może 12 miesięcy liczonych od dnia wydania przez organ egzekucyjny postanowienia o umorzenia postępowania egzekucyjnego na podstawie art. 59 § 2 ustawy egzekucyjnej (stwierdzona bezskuteczność egzekucji). Jednakże wierzyciel zobligowany jest do bezzwłocznego zainicjowania czynności zmierzających do zastosowania środków egzekucyjnych w przypadku ujawnienia majątku zobowiązanego, którego wartość przekracza kwotę szacowanych wydatków egzekucyjnych. Dokonana zmiana dotyczy również przypadków wskazanych w art. 6 § 1d ustawy egzekucyjnej i związanych następstwem prawnym wynikającym z odpowiedzialności podatkowej osób trzecich (na podstawie przepisów art. 107 i n. Ordynacji podatkowej ${ }^{18}$ ). $\mathrm{W}$ tych przypadkach wierzyciel kieruje do zobowiązanego wezwanie do złożenia wykazu majątku oraz źródeł dochodu. Elementy wezwania określone zostały w $\S 6$ Rozporządzenia Ministra Finansów z dnia 30 grudnia 2015 r. w sprawie trybu postępowania wierzycieli należności pieniężnych i dotyczą informacji o nieruchomościach, rzeczach ruchomych, prawach majątkowych oraz środkach pieniężnych należących do zobowiązanego. Niezłożenie w przewidzianym terminie wykazu majątku lub niewykazanie składników majątkowych przewyższających szacowaną kwotę wydatków egzekucyjnych upoważnia wierzyciela do odstąpienia od czynności zmierzających do zastosowania środków egzekucyjnych na maksymalny okres 12 miesięcy, liczonych od dnia doręczenia zobowiązanemu wezwania.

Wprowadzone zmiany trzeba ocenić pozytywnie. Tezy zaprezentowane $\mathrm{w}$ uzasadnieniu projektu ustawy ${ }^{19}$ znalazły aprobatę również $\mathrm{w}$ najnowszych poglądach doktryny ${ }^{20}$. Niezaprzeczalnie, intencje ustawodawcy skierowane były na usprawnienie oraz racjonalizację egzekucji administracyjnej. Dokonanymi zmianami prawodawca podkreśla, że celem egzekucji jest doprowadzenie do wykonania obowiązku, nie

${ }^{18}$ Tekst jedn. Dz.U. 2015, poz. 613 ze zm.

${ }^{19}$ Druk sejmowy nr 3320/VII kadencja.

${ }^{20}$ W. Piątek, A. Skoczylas, Komentarz do art. 6, nb. 11, w: Postępowanie egzekucyjne w administracji. Komentarz, pod red. R. Hausera, A. Skoczylasa, wyd. 8, Warszawa 2016, dostępne także w Systemie Informacji Prawnej Legalis, http://sip.legalis.pl (dostęp: 17 III 2016). 
zaś generowanie dodatkowych kosztów w postaci wydatków egzekucyjnych. Dodatkowo zauważa się, iż w sprawach mniejszej wagi działania informacyjne będą skuteczniejsze i efektywniejsze ekonomicznie niż stosowanie środków przymusu i angażowanie aparatu państwa.

\section{Tryb rozpoznawania skargi na czynności egzekucyjne i przewlekłość postępowania oraz skarg incydentalnych}

Zagadnieniem wymagającym omówienia w tej części opracowania jest zmiana trybu rozpoznawania skarg na czynności egzekucyjne organu egzekucyjnego lub egzekutora oraz skarg na przewlekłość postępowania egzekucyjnego z mocy art. 54 ustawy egzekucyjnej. Najbardziej istotnym aspektem dokonanych zmian jest przesunięcie właściwości organu do orzekania w sprawach skarg na czynności egzekucyjne lub skarg na przewlekłość postępowania ${ }^{21}$. Postanowieniami ustawy o administracji podatkowej organem właściwym do rozpoznania tego typu skarg w pierwszej instancji został wyznaczony organ egzekucyjny. Przeprowadzona zmiana sprawia, że na temat uchybień (zaniechań) poczynionych w trakcie postępowania egzekucyjnego orzekać będzie organ, który dane czynności przedsięwziął (zaniechał ich przedsięwzięcia). $\mathrm{W}$ ocenie ustawodawcy zmiana ta ma na celu usprawnienie działania administracji podatkowej ${ }^{22}$, w tym funkcjonowania organów egzekucyjnych. Ustawa nowelizująca doprecyzowała również element proceduralny związany z realizacją uprawnienia do wniesienia skargi na czynności egzekucyjne przez zobowiązanego. W stanie prawnym obowiązującym do dnia 31 grudnia 2015 r. ustawa przewidywała, że skargę wnosi się w terminie 14 dni od daty dokonania zakwestionowanej czynności. Dokonana zmiana art. $54 \S 4$ ustawy egzekucyjnej zrealizowała postulat de lege ferenda podnoszony w orzecznictwie sądów administracyjnych ${ }^{23}$, wskazujący na konieczność przesunięcia początku biegu terminu do złożenia skargi na dzień powiadomienia zobowiązanego o dokonaniu kwestionowanej przez niego czynności. Zmodyfikowany został również katalog możliwych rozstrzygnięć organu w przypadku uwzględnienia

${ }^{21}$ Druk sejmowy nr 3320/VII kadencja.

22 Ibidem.

${ }^{23}$ Np. w wyroku Wojewódzkiego Sądu Administracyjnego (WSA) w Warszawie z 25 V 2007 r., sygn. III SA/Wa 1104/06, Centralna Baza Orzeczeń Sądów Administracyjnych, http://orzeczenia.nsa.gov.pl/doc/D1BB981DE1 (dostęp: 25 III 2016). 
skargi. W art. $54 \S 5$ a ustawy egzekucyjnej przewidziano, że organ egzekucyjny uchyla zakwestionowaną czynność egzekucyjną lub usuwa stwierdzone wady czynności ${ }^{24}$. W przypadku nieuwzględniania skargi zobowiązanemu przysługuje prawo do wniesienia zażalenia do organu nadzoru na zasadach ogólnych określonych w art. $17 \S 1$ ustawy egzekucyjnej. Tożsame zmiany dotyczą trybu wnoszenia i rozpoznawania środka zaskarżenia ma podstawie art. 107 § 2a ustawy egzekucyjnej (skarga zobowiązanego, wierzyciela albo uczestnika licytacji na naruszenie przepisów o przeprowadzeniu licytacji) oraz z art. 110z ustawy egzekucyjnej (skarga na czynności organu egzekucyjnego dotyczące obwieszczenia o licytacji nieruchomości).

Wprowadzone przez ustawodawcę zmiany należy przyjąć $\mathrm{z}$ aprobata, jednakże $z$ pewnymi zastrzeżeniami. Zasadne $\mathrm{z}$ punktu widzenia ekonomiki oraz sprawności postępowania było wyłączenie z rozpoznawania indywidualnych spraw egzekucyjnych ministra finansów. Można stwierdzić, że brak było jakichkolwiek przesłanek natury faktycznej lub prawnej, aby przedmiotowe skargi w II instancji były rozpoznawane przez naczelny organ administracji rządowej. Nawet w przypadku skorzystania przez zobowiązanego ze środka prawnego mającego najdalej idące oddziaływanie procesowe - zarzutów na prowadzoną egzekucję sprawa w II instancji nie była rozpoznawana przez ministra finansów jako organ odwoławczy. Ponadto słuszne jest umożliwienie organowi egzekucyjnemu usunięcie stwierdzonych wad w ramach uwzględnienia skargi. Opisana zmiana pozwoli uzależnić podjęte przez organ egzekucyjny rozstrzygnięcie od przedmiotu skargi oraz rodzaju stwierdzonej wadliwości ${ }^{25}$.

Krytycznie jednak trzeba ocenić przyjętą przez ustawodawcę właściwość organu rozpoznającego skargę. Już prima facie przyjęta regulacja stoi w sprzeczności z łacińską paremią nemo iudex in causa sua. Zgodnie bowiem $\mathrm{z}$ definicją legalną zawartą $\mathrm{w}$ art. 1a pkt 2 ustawy egzekucyjnej czynnością egzekucyjną są „wszelkie podejmowane przez organ egzekucyjny działania zmierzające do zastosowania lub zrealizowania środka egzekucyjnego". Niezasadne jest zatem powierzanie organowi egzekucyjnemu oceny jego własnych działań. Właściwsze zdaje się

${ }^{24}$ Zasadniejsze byłoby jednak zastosowanie $\mathrm{w}$ tym przypadku funktora alternatywy rozłącznej "albo", gdyż organ uwzględniający skargę albo uchyli zaskarżoną czynność, albo ją konwaliduje poprzez usunięcie stwierdzonych wad.

${ }^{25}$ R. Hauser, Z. Leoński, J. Olszanowski, Komentarz do art. 54, nb. 5, w: Postępowanie egzekucyjne w administracji... 
rozciągnięcie zastosowania na omawiane przypadki skarg dyspozycji wyrażonej w znowelizowanym art. 17 § 1b ustawy egzekucyjnej. Przyjęcie tego rozwiązania sprawiłoby, że skargi byłyby rozpoznawane przez organ nadzoru, pełniący zarówno funkcję organu I instancji, jak i organu odwoławczego. Proponowany model nie naruszałby w żadnym zakresie interesu stron i uczestników postępowania, bowiem na podstawie art. 3 $\S 2$ pkt 3 Ustawy z dnia 30 sierpnia 2002 r. Prawo o postępowaniu przed sądami administracyjnymi ${ }^{26}$ na tego typu orzeczenia służy skarga do sądu administracyjnego.

\section{Sposób i forma orzekania przez organ egzekucyjny o nieprzystąpieniu do egzekucji}

Ustawa o administracji podatkowej wprowadziła również odmienną od dotychczasowej regulację działań organu egzekucyjnego na etapie postępowania poprzedzającym zastosowanie środków egzekucyjnych. Katalog przesłanek (zarówno pozytywnych, jak i negatywnych) został w sposób wyczerpujący ujęty w art. 29 § 2 ustawy egzekucyjnej. Pierwsza (pkt 1) oraz trzecia (pkt 3) podstawa nieprzystąpienia do egzekucji wyszczególniona w powołanym przepisie prawa stanowi powtórzenie regulacji obowiązującej w stanie dotychczasowym i jako taka nie będzie podlegać omówieniu w niniejszym opracowaniu. Głębszej analizy wymagają natomiast przesłanki dodane do ustawy egzekucyjnej na mocy ustawy nowelizującej w art. $29 \S 2$ pkt 2 ustawy egzekucyjnej, polegające na orzekaniu o nieprzystąpieniu do egzekucji w formie zawiadomienia.

Dokonana zmiana daje organowi egzekucyjnemu kompetencje do nieprzystąpienia do egzekucji, jeżeli uprawdopodobni się, że w ramach egzekucji, której przeprowadzenia żąda wierzyciel, nie uzyska się kwoty przewyższającej wydatki egzekucyjne. W przyjętej regulacji widoczne jest podobieństwo do uprawnienia wierzyciela przyjętego w art. 6 § 1c ustawy egzekucyjnej (omówionej szczegółowo w punkcie pierwszym niniejszego opracowania), a ich cechą wspólną jest odstąpienie od działania w związku z uprawdopodobnieniem bezcelowości egzekucji już na etapie poprzedzającym jej faktyczne wszczęcie (przed zastosowaniem środków egzekucyjnych). Kryterium, na podstawie którego organ egzekucyjny orzeknie o przystąpieniu albo nieprzystąpieniu do

${ }^{26}$ Tekst jedn. Dz.U. 2012, poz. 1270 ze zm. 
egzekucji administracyjnej, jest badanie, czy w ramach egzekucji możliwa będzie do uzyskania kwota przewyższająca potencjalne wydatki egzekucyjne, jakie powstaną w przyszłej sprawie egzekucyjnej. Biorąc pod uwagę powyższe, należy stwierdzić, że w zmienionym stanie prawnym prognoza (kalkulacja) organu egzekucyjnego w zakresie możliwych do uzyskania kwot determinuje w ogóle przystąpienie przez ten organ do egzekucji (ściągania) skierowanych przez wierzyciela należności wynikających z przedłożonych tytułów wykonawczych. Warunkiem koniecznym nieprzystąpienia do egzekucji jest jedynie uprawdopodobnienie przez organ egzekucyjny racji, które stały się podstawą podjętej decyzji. Tym samym przewidziane przez ustawodawcę uprawdopodobnienie organ egzekucyjny budować będzie na podstawie wiadomości o osobie i majątku zobowiązanego, jakie powziął w związku z wykonywaniem ustawowych czynności. Jako przykład można wskazać sytuację, w której organ egzekucyjny prowadzi równolegle inne egzekucje w stosunku do osoby tego samego zobowiązanego, w których nie udało się uzyskać żadnych sum, ma wiedzę o majątku zobowiązanego, jednak obciążonym prawami, które podlegają zaspokojeniu w wyższych kategoriach, oraz o faktycznym nieistnieniu zobowiązanego (np. spółka podlegająca wpisowi do Krajowego Rejestru Sądowego i z tego rejestru niewykreślona pomimo zaprzestania działalności gospodarczej).

Przyjąć można, że ustawodawca upoważnił organ egzekucyjny do nieprzystępowania do egzekucji na podstawie omawianego przepisu prawa, gdyż to właśnie ten organ posiada najbogatsze informacje o podmiotach (zobowiązanych) poddanych jego jurysdykcji. Ocena dokonana przez organ egzekucyjny nie może być jednak w pełni dowolna, wręcz przeciwnie - musi zostać poparta zgromadzonymi dowodami ${ }^{27}$, takimi jak protokoły o stanie majątkowym zobowiązanego, notatki służbowe z przeprowadzonych czynności, informacje uzyskane w trybie art. 36 ustawy egzekucyjnej. Omawiana instytucja pozwala również chronić interesy majątkowe wierzycieli, którzy z mocy prawa nie podlegają zwolnieniu z uiszczenia niepobranych od zobowiązanego kosztów egzekucyjnych. Przypomnieć trzeba, że na mocy art. 64c § 4 ustawy egzekucyjnej nieściągnięte od zobowiązanego koszty egzekucyjne (tj. opłaty określone w art. 64 ustawy egzekucyjnej oraz wydatki przewidziane $\mathrm{w}$ art. 64b ustawy egzekucyjnej) obciążają wierzyciela,

${ }^{27}$ W. Piątek, A. Skoczylas, Komentarz do art. 29, nb. 9, w: Postępowanie egzekucyjne wadministracji... 
który obowiązany jest do ich pokrycia pod rygorem wyegzekwowania w trybie egzekucji administracyjnej. Zamiarem ustawodawcy była również poprawa efektywności funkcjonowania organów egzekucyjnych poprzez skoncentrowanie działań w sprawach, gdzie możliwe jest osiągnięcie celu egzekucji ${ }^{28}$. Przeprowadzone zmiany wskazują zatem, iż głównym ratio legis ustawy egzekucyjnej jest zwiększenie liczby postępowań zakończonych poprzez zapłatę.

Drugim zagadnieniem wymagającym omówienia w ramach zmian art. 29 ustawy egzekucyjnej jest forma orzekania przez organ egzekucyjny o nieprzystąpieniu do egzekucji. Ustawodawca zdecydował, że podstawową formą działania organu egzekucyjnego w tym zakresie będzie zawiadomienie. W kierowanym do wierzyciela zawiadomieniu powinna zostać przywołana przyczyna nieprzystąpienia do egzekucji, którą być musi jedna z przesłanek wymienionych w art. 29 \& 2 ustawy egzekucyjnej. Obowiązek orzeczenia $w$ formie zaskarżalnego postanowienia (jak miało to miejsce w czasie przed wejściem w życie ustawy o administracji podatkowej) zaktualizuje się dopiero w przypadku złożenia przez wierzyciela w terminie 14 dni od daty doręczenia mu zawiadomienia wniosku o wydanie postanowienia. Wskazany termin ma charakter procesowy, a zatem podlega przywróceniu na zasadach opisanych w art. 58 i $59^{29}$ Kodeksu postępowania administracyjnego ${ }^{30}$.

Zgodnie z uzasadnieniem zamieszczonym w projekcie ustawy o administracji podatkowej ${ }^{31}$ słuszne jest umożliwienie stwierdzania przez organ o nieprzystąpieniu do egzekucji w trybie odformalizowanym, co tym samym usprawnić ma przebieg postępowania. Forma zawiadomienia szczególnie sprawdzi się w przypadku oczywistych błędów w treści tytułu wykonawczego, kiedy brak jest wątpliwości o poczynionych przez wierzyciela uchybieniach. Kontrowersyjne może natomiast okazać się orzekanie o nieprzystąpieniu do egzekucji na podstawie art. $29 \S 2$ pkt 2 ustawy egzekucyjnej. Należy pamiętać, że w administracyjnym postępowaniu egzekucyjnym nie funkcjonuje reguła wyrażona $w$ art. 8 ust. 5 Ustawy z dnia 29 sierpnia 1997 r. o komornikach sądowych i egzeku$\mathrm{cji}^{32}$, która pozwala wierzycielowi dla dochodzenia swej należności na

${ }^{28}$ Druk sejmowy nr 3320/VII kadencja.

${ }^{29}$ W. Piątek, A. Skoczylas, Komentarz do art. 29, nb. 2, w: Postępowanie egzekucyjne wadministracji...

${ }^{30}$ Tekst jedn. Dz.U. 2016, poz. 23 ze zm., dalej „k.p.a.”.

${ }^{31}$ Druk sejmowy nr 3320/VII kadencja.

${ }^{32}$ Tekst jedn. Dz.U. 2015, poz. 709 ze zm. 
wybór dowolnego komornika sądowego na terytorium Rzeczypospolitej Polskiej. W ramach omawianego postępowania wierzyciel bezwzględnie kierować musi wniosek o przeprowadzenie egzekucji do organu egzekucyjnego właściwego miejscowo na podstawie art. $22 \S 2$ ustawy egzekucyjnej (poza wyjątkami w tym przepisie prawa wskazanymi). Oznacza to, że odmowa podjęcia egzekucji przez organ egzekucyjny w sposób całkowity pozbawi wierzyciela możliwości uzyskania zaspokojenia. $W$ tym przypadku jest wielce prawdopodobne, że wierzyciele kwestionować będą ocenę organu egzekucyjnego. Może to doprowadzić do sytuacji dwukrotnego rozpoznawania przez organ egzekucyjny tej samej sprawy w tym samym zakresie, a postać wydanego rozstrzygnięcia różnić się będzie jedynie formą.

Sporządzone przez organ egzekucyjny zawiadomienie zawierać powinno wszystkie elementy postanowienia, takie jak data wydania, oznaczenie organu oraz stron, podstawa prawna, uzasadnienie faktyczne i prawne, pouczenie o trybie odwołania (żądania wydania postanowienia) oraz podpis upoważnionego pracownika. Może zatem zdarzyć się, że postulat ustawodawcy w tym wymiarze nie zostanie zrealizowany, a tryb procedowania zamiast ulec usprawnieniu i odformalizowaniu stanie się zbędnie rozbudowany. Dlatego zasadnym postulatem de lege ferenda jest wprowadzenie obligatoryjnego orzekania o nieprzystapieniu do egzekucji na podstawie art. 29 § 2 pkt 2 ustawy egzekucyjnej bezpośrednio $\mathrm{w}$ trybie postanowienia.

\section{Uprawnienie organu egzekucyjnego do żądania udzielenia informacji oraz wyjaśnień}

Ustawa nowelizująca wprowadziła istotne zmiany w zakresie uprawnień organu egzekucyjnego do żądania od uczestników postępowania egzekucyjnego, organów administracji publicznej (oraz podległych im jednostek), a także od innych podmiotów informacji i wyjaśnień niezbędnych do wszczęcia i prowadzenia postępowania egzekucyjnego. Przedstawione kompetencje przysługują również Centralnemu Biuru Łacznikowemu ${ }^{33}$, o którym mowa w art. 9 ustawy o wzajemnej pomocy.

${ }^{33}$ Jest to organ powołany na mocy ustawy o wzajemnej pomocy do kontaktów z państwami członkowskimi i państwami trzecimi w zakresie wykonywania wzajemnej pomocy, dalej „CBL”. 
Przed przystąpieniem do analizy poczynionych zmian w zakresie obowiązku informacyjnego wobec organu egzekucyjnego (CBŁ) zaznaczyć trzeba, że przepis art. 36 ustawy egzekucyjnej ma pierwszorzędne znaczenie podczas ustalania przez ten organ informacji o sytuacji majątkowej zobowiązanego ${ }^{34}$. Wprowadzone $\mathrm{w}$ ramach dodanych do art. 36 ustawy egzekucyjnej § 1c-1d zmiany expressis verbis określają zakres informacji, jakie banki (art. 36 § 1c ustawy egzekucyjnej), spółdzielcze kasy oszczędnościowo-kredytowe (art. 36 § 1d ustawy egzekucyjnej), podmioty prowadzące rachunki papierów wartościowych lub inne rachunki (art. 36 § 1d ustawy egzekucyjnej) obowiązane są udzielić na żądanie organu egzekucyjnego lub CBŁ. Rodzaj informacji, jakie mają obowiązek wskazać banki (oraz podmioty wymienione $\mathrm{w}$ art. $36 \S 1 \mathrm{~d}$ ustawy egzekucyjnej), został precyzyjnie zdefiniowany w treści art. 36 $\S 1$ c ustawy egzekucyjnej ${ }^{35}$.

Warto odnotować, że przepis art. 115 ustawy o wzajemnej pomocy wprowadził już do Ustawy z dnia 29 sierpnia 1997 r. Prawo bankowe ${ }^{36}$ art. 105 ust. 1 pkt 2 lit. v jako podstawę prawną zwalniającą bank z tajemnicy bankowej, a zarazem obligująca go do udzielenia informacji w przypadku wystąpienia ze stosownym żądaniem przez administracyjny organ egzekucyjny lub CBŁ w ramach wykonywania przez te organy ich ustawowych zadań. Praktyka jednak pokazała, że banki, interpretując

${ }^{34}$ W. Piątek, A. Skoczylas, Komentarz do art. 29, nb. 1, w: Postępowanie egzekucyjne w administracji...

${ }^{35}$ Paragraf 1c ustawy egzekucyjnej:

„Na żądanie organu egzekucyjnego lub centralnego biura łącznikowego banki są obowiązane do przekazywania informacji dotyczących zobowiązanego lub podmiotu, o którym mowa w art. 3 pkt 8 ustawy o wzajemnej pomocy, w zakresie:

1) posiadanych rachunków bankowych lub posiadanych pełnomocnictw do dysponowania rachunkami bankowymi, liczby tych rachunków lub pełnomocnictw, obrotów i stanów tych rachunków, z podaniem wpływów, obciążeń rachunków i ich tytułów oraz odpowiednio ich nadawców i odbiorców;

2) posiadanych rachunków pieniężnych, rachunków papierów wartościowych lub posiadanych pełnomocnictw do dysponowania takimi rachunkami, liczby tych rachunków, a także obrotów i stanów tych rachunków;

3) zawartych umów kredytowych lub umów pożyczki, z podaniem wysokości zobowiązań wynikających z tych kredytów lub pożyczek, celów, na jakie zostały udzielone, i sposobu zabezpieczenia ich spłaty, a także umów depozytowych i umów udostępniania skrytek sejfowych;

4) nabytych za pośrednictwem banków akcji Skarbu Państwa lub obligacji Skarbu Państwa, a także obrotu tymi papierami wartościowymi;

5) obrotu wydawanymi przez banki certyfikatami depozytowymi lub innymi papierami wartościowymi".

${ }^{36}$ Tekst jedn. Dz.U. 2015, poz. 128 ze zm., dalej „Prawo bankowe”. 
brzmienie przywołanego przepisu, uzupełniały rezultat wykładni językowej wykładnią systemowa, wnioskując, że uprawnienie organu egzekucyjnego oraz CBŁ dotyczy wyłącznie wykonywania zadań związanych z realizacją wniosków o udzielenie wzajemnej pomocy, o których mowa w art. 73 ustawy o wzajemnej pomocy. Spowodowane to było przyjęciem przez banki założenia, że zwrot "W zakresie wykonywania ich ustawowych zadań" zawarty w art. 115 ustawy o wzajemnej pomocy odnosi się do sfery działania organu egzekucyjnego dotyczącej jedynie zadań sformułowanych w ustawie o wzajemnej pomocy. Tym samym organy egzekucyjne napotykały na znaczne trudności w trakcie występowania do banków, bowiem te w powołaniu na powyższą argumentację uzależniały udzielenie informacji od wskazania przez organ egzekucyjny, że prowadzone postępowanie egzekucyjne jest realizacją wzajemnej pomocy ${ }^{37}$.

Można zatem przyjąć, że ustawodawca, chcąc wyeliminować problemy związane z interpretacją art. 105 ust. 1 pkt 2 lit. v Prawo bankowe, wskazał wprost w treści art. 36 § 1c ustawy egzekucyjnej zakres obowiązku informacyjnego banku wobec organu egzekucyjnego (CBŁ). Przewidując możliwe problemy w stosowaniu nowego przepisu (art. 36 $\S 1 c-1 d$ ustawy egzekucyjnej) przez adresatów zapytań, zasadne jest przywołanie poglądu zaprezentowanego przez Naczelny Sąd Administracyjny (NSA) w wyroku z 1 września 2011 r. ${ }^{38}$, zgodnie z którym organ egzekucyjny prowadzący egzekucję w stosunku do konkretnego zobowiązanego posiada interes prawny do uzyskania informacji o potencjalnym majątku zobowiązanego, którą może posiadać podmiot, do którego skierowano zapytanie z art. 36 ustawy egzekucyjnej. Uprawnienie organu egzekucyjnego nie może być zatem ograniczane poprzez powoływanie się przez adresata wezwania $z$ art. 36 ustawy egzekucyjnej na to, że kierujący wezwanie organ nie prowadzi egzekucji z zastosowaniem środka egzekucyjnego, którego dane zapytanie dotyczy $^{39}$. W praktyce pojawiały się przypadki, kiedy bank uzależniał udzielenie odpowiedzi od skierowania zajęcia rachunku do tego banku czy też wskazywania zestawienia obrotów na rachunku zobowiązanego

${ }^{37}$ Wzajemną pomoc należy rozumieć jako wykonywanie wniosków o udzielenie informacji, powiadomienie lub odzyskanie należności pieniężnych.

${ }^{38}$ Por. wyrok NSA z 1 IX 2011 r., sygn. I OSK 1444/10, Centralna Baza Orzeczeń Sądów Administracyjnych, http://orzeczenia.nsa.gov.pl/doc/F1D1BCE1C3 (dostęp: 25 III 2016).

${ }^{39}$ R. Hauser, W. Piątek, Komentarz do art. 36, nb. 4, w: Postępowanie egzekucyjne w administracji... 
tylko od momentu wpływu do banku zawiadomienia o zajęciu tego rachunku. Zasadne zatem jest przyjęcie stanowiska, że w nowym stanie prawnym organ egzekucyjny (CBŁ) jest uprawniony do uzyskania od banku wszelkich informacji mieszczących się w katalogu wyszczególnionym $\mathrm{w}$ art. 36 § 1c ustawy egzekucyjnej.

\section{Udzielanie upoważnienia przez organy jednostek samorządu terytorialnego do wykonywania funkcji wierzyciela oraz organu egzekucyjnego}

Dokonane $\mathrm{w}$ drodze nowelizacji ustawy egzekucyjnej zmiany wprowadziły możliwość upoważnienia kierownika (pracowników) komórki nieposiadającej osobowości prawnej wchodzącej w skład jednostki samorządu terytorialnego do wykonywania zadań wierzyciela oraz organu egzekucyjnego ${ }^{40}$. W pierwszej kolejności należy zaznaczyć, że nowy stan prawny nie rozszerza katalogu podmiotów uprawnionych do występowania w ramach administracyjnego postępowania egzekucyjne$\mathrm{go}^{41}$. Ustalanie uprawnionego do wystąpienia $\mathrm{z}$ wnioskiem o wszczęcie egzekucji wierzyciela lub właściwego organu egzekucyjnego następować będzie na dotychczasowych zasadach, tj. zgodnie z właściwością rzeczową wskazaną w art. 5 lub art. $19 \S 2$ ustawy egzekucyjnej ${ }^{42}$.

Można założyć, że zamysłem ustawodawcy było wprowadzenie możliwości dokonania upoważniania przez organ wykonawczy jednostki samorządu terytorialnego do wykonywania działań o charakterze wierzycielskim czy egzekucyjnym kierowników wyspecjalizowanych wydziałów. Brak omawianej legitymacji był powodem błędnej interpretacji przepisów ustawy egzekucyjnej przez podmioty ją stosujące. Szczególnie widoczny stał się problem występowania w postępowaniu egzekucyjnym po stronie wierzyciela jednostek pomocniczych organów samorządu terytorialnego, które w toczącym się postępowaniu powoływały się na upoważnienie udzielone przez organ stanowiący lub wykonawczy gminy (rzadziej powiatu lub województwa). Sądy administracyjne rozpoznające sprawy dotyczące delegacji kompetencji wierzycielskich na komórki wspierające (działy, wydziały itp.) wyrażały jednak spójny pogląd, że jakikolwiek transfer uprawnień w tym

\footnotetext{
${ }^{40}$ W. Piątek, Komentarz do art. 17b, nb. 1, w: Postępowanie egzekucyjne w administracji...

${ }^{41}$ Druk sejmowy nr 3320/VII kadencja.

42 Ibidem.
} 
zakresie jest niedopuszczalny ${ }^{43}$. Zauważyć trzeba, co trafnie podniósł w uzasadnieniu wyroku z 19 lutego 2013 r. Wojewódzki Sąd Administracyjny w Gdańsku ${ }^{44}$, że organy administracji publicznej obowiązane są z urzędu przestrzegać przepisów regulujących ich uprawnienia, a dekoncentracja kompetencji (zarówno na zewnątrz, jak i wewnątrz struktury organizacyjnej organu) może nastąpić tylko w przypadkach prawem przewidzianych.

Zmieniony stan prawny dopuszcza natomiast przyznanie uprawnień do wykonywania praw wierzyciela (oraz organu egzekucyjnego wyspecjalizowanego, o którym mowa w art. 19 § 2 ustawy egzekucyjnej) kierownikom nieposiadających osobowości prawnej jednostek organizacyjnych jednostek samorządu terytorialnego, a także na wniosek tych kierowników - pracownikom podległych im komórek. Dokonane zmiany mają umożliwić zgodne z prawem powierzenie kompetencji wierzyciela (organu egzekucyjnego) ściśle wyspecjalizowanym jednost$\mathrm{kom}^{45}$, co sprzyjać ma usprawnieniu postępowania ${ }^{46}$. Ustawodawca nie określił szczegółowej formy i trybu dokonywania upoważnienia przez właściwy organ jednostki samorządu terytorialnego do wykonywania $\mathrm{w}$ jego imieniu funkcji wierzyciela (organu egzekucyjnego) ${ }^{47}$. Należy zatem przyjąć, że delegacja uprawnienia odbywać się będzie w drodze czynności materialno-technicznej (tj. działania organu administracji, które będąc czynnością faktyczna, oparte jest na wyraźnej podstawie prawnej i wywołuje konkretne skutki prawne $\left.{ }^{48}\right)$, która utrwalona zostać powinna w aktach sprawy, a organ upoważniony winien się na nią powoływać $w$ ramach realizacji powierzonych zadań ${ }^{49}$. Jeżeli zatem legitymacja do działania wierzycieli lub organów egzekucyjnych wyeksplikowanych w art. 19 § 1-8 ustawy egzekucyjnej wynika z mocy

${ }^{43}$ Por. wyroki: NSA z 16 V 2012 r., sygn. II FSK 355/12, http://orzeczenia.nsa.gov. pl/doc/3E1BDD89D7; WSA w Gdańsku z 22 XII 2011 r., sygn. III SA/Gd 476/11, http:// orzeczenia.nsa.gov.pl/doc/8298B28E82; WSA w Gliwicach z 23 X 2013 r., sygn. I SA/ Gl 1389/12, Centralna Baza Orzeczeń Sądów Administracyjnych, http://orzeczenia.nsa. gov.pl/doc/D8D1D1C7BC (dostęp: 22 III 2016).

${ }^{44}$ Por. wyrok WSA w Gdańsku z 19 II 2013 r., sygn. I SA/Gd 1201/12, Centralna Baza Orzeczeń Sądów Administracyjnych, http://orzeczenia.nsa.gov.pl/doc/68EF7C9D4D (dostęp: 22 III 2016).

${ }^{45}$ Druk sejmowy nr 3320/VII kadencja.

${ }^{46}$ W. Piątek, A. Skoczylas, Komentarz do art. 19, nb. 2, w: Postępowanie egzekucyjne wadministracji...

${ }^{47}$ W. Piątek, Komentarz do art. 17b, nb. 2, w: Postępowanie egzekucyjne w administracji...

${ }^{48}$ J. Starościak, Prawne formy działania administracji, Warszawa 1957, s. 286.

${ }^{49}$ W. Piątek, Komentarz do art. 17b, nb. 2, w: Postepowanie egzekucyjne w administracji... 
samego prawa, to podmioty wykonujące swe zadania na podstawie upoważnień udzielonych na mocy art. 17b lub art. $19 \S 2$ a ustawy egzekucyjnej obowiązane są przy podejmowaniu czynności powołać się na i okazać dokument powierzający kompetencje ${ }^{50}$.

\section{Elementy formalne tytułu wykonawczego (zarządzenia zabezpieczenia)}

Omawiane zagadnienie dotyczy zmian odnoszących się do obligatoryjnych elementów, jakie zawierać musi kierowany przez wierzyciela do organu egzekucyjnego tytuł wykonawczy, aby na jego podstawie mogła zostać skutecznie zainicjowana egzekucja administracyjna. Ustawodawca w art. $26 \S 1$ ustawy egzekucyjnej wskazał, że tytuł wykonawczy stosowany w egzekucji administracyjnej sporządza się według ustalonego wzoru. Sam dokument zawierać winien elementy wskazane w art. 27 § 1 ustawy egzekucyjnej. Nowelizacja ustawy egzekucyjnej, która weszła w życie z dniem 1 stycznia 2016 r., dokonała zmiany redakcji art. 27 $\S 1$ pkt 2 ustawy egzekucyjnej w zakresie ustanowienia obowiązku wskazywania przez wierzyciela w treści tytułu wykonawczego numeru identyfikacji podatkowej (NIP) lub numeru Powszechnego Elektronicznego Systemu Ewidencji Ludności (PESEL), jeżeli zobowiązany taki numer posiada. Stwierdzić trzeba, że w zmienionym stanie prawnym katalog obligatoryjnych elementów formalnych tytułu wykonawczego został powiększony o zamieszczenie identyfikatorów oznaczających zobowiązanego.

Dokonaną przez ustawodawcę zmianę należy ocenić pozytywnie, jednak zarazem należy pamiętać, że nowe obowiązki nałożone na wierzyciela mogą wydłużyć procedurę związaną z wystawieniem tytułu wykonawczego. Niewątpliwie prawodawca nawiązywał do regulacji prawnej zawartej w Rozporządzeniu Ministra Sprawiedliwości z dnia 6 sierpnia 2014 r. w sprawie określenia brzmienia klauzuli wykonalności ${ }^{51}$, gdzie przewidziano wskazanie w treści klauzuli wykonalności nadawanej sądowym tytułom egzekucyjnym tożsamych identyfikatorów opisujących dłużnika (zobowiązanego) ${ }^{52}$. Poczynione zmiany

\footnotetext{
${ }^{50}$ Ibidem.

${ }^{51}$ Dz.U. poz. 1092.

${ }^{52}$ Ustawodawca jednak nie zdecydował się na oznaczanie zobowiązanego niebędącego osobą fizyczną poprzez przypisanie w tytule wykonawczym jego numeru nadanego
} 
normatywne mają na celu usprawnienie egzekucji oraz zwiększenie poziomu ochrony praw zobowiązanych. Oznaczenie dłużnika za pomocą niepowtarzalnego numeru NIP lub PESEL spowoduje uniknięcie pomyłek co do podmiotu, w stosunku do którego kierowana jest egzekucja $^{53}$. Jednocześnie przesądzona została kwestia określenia organu, na którym ciąży obowiązek oznaczenia zobowiązanego. W poprzednim stanie prawnym (sprzed 1 stycznia 2016 r.) mogło się zdarzyć, że pomimo poprawnie wystawionego tytułu wykonawczego organ egzekucyjny podejmować musiał czynności w celu "dopasowania” osoby wskazanej w tytule wykonawczym do rzeczywistego adresata obowiązku (np. w przypadku osób o tym samym imieniu i nazwisku mieszkających pod tym samym adresem). Wprowadzone zmiany umacniają rozdział kompetencyjny pomiędzy wierzycielem a organem egzekucyjnym. Zadaniem organu wykonującego jest bowiem doprowadzenie do przymusowego wypełnienia obowiązku, nie zaś ustalanie podmiotu, który podlega temu obowiązkowi.

W tym miejscu należy też zaakcentować, że wprowadzenie omawianego obowiązku obliguje wierzyciela niedysponującego własnym rejestrem (lub który nie uzyskał potrzebnych identyfikatorów w ramach wcześniej prowadzonego postępowania rozpoznawczego) do wystąpienia do podmiotów prowadzących właściwe rejestry z wnioskiem o udostępnienie niezbędnych danych. Ogólne upoważnienie dla wierzycieli zawarte jest w art. $36 \S 1$ ustawy egzekucyjnej, zaś skonkretyzowane (odnoszące się do poszczególnych rejestrów): do uzyskania numeru $z$ rejestru PESEL - w art. 46 § 1 Ustawy z dnia 24 września 2010 r. o ewidencji ludności ${ }^{54}$, a do uzyskania numeru NIP z Centralnego Rejestru Podmiotów - Krajowej Ewidencji Podatników w art.15 ust. 2 Ustawy z dnia 13 października 1995 r. o zasadach ewidencji i identyfikacji podatników i płatników ${ }^{55}$.

Uzupełniająco wskazać można, że ustawodawca, zmieniając redakcję art. $27 \S 1$ pkt 2 ustawy egzekucyjnej, zrezygnował z zamieszczenia w treści przepisu danych dotyczących miejsca zatrudnienia zobowiązanego.

w Krajowym Rejestrze Sądowym. Zważając na jawność oraz powszechność dostępu do sądowego rejestru przedsiębiorców, transponowanie opisanej regulacji na grunt administracyjnego postępowania egzekucyjnego ułatwiłoby wierzycielom uzyskanie wymaganych prawem identyfikatorów.

${ }^{53}$ Druk sejmowy nr 3320/VII kadencja.

${ }^{54}$ Tekst jedn. Dz.U. 2015, poz. 388 ze zm.

${ }_{55}$ Tekst jedn. Dz.U. 2012, poz. 1314 ze zm. 
Niezmieniona wersja przepisu zawierała w sobie zbędne powtórzenie, gdyż obowiązkiem wierzyciela na mocy Rozporządzenia Ministra Finansów z dnia 30 grudnia 2015 r. w sprawie postępowania wierzycieli należności pieniężnych (a wcześniej rozporządzenia Ministra Finansów z dnia 20 maja 2014 r. w sprawie trybu postępowania wierzycieli należności pieniężnych przy podejmowaniu czynności zmierzających do zastosowania środków egzekucyjnych ${ }^{56}$ ) jest informowanie organu egzekucyjnego o znanych składnikach majątkowych zobowiązanego, w tym przysługującym wynagrodzeniu za pracę.

Opisywane zmiany w sposób analogiczny tyczą się również warunków formalnych zarządzenia zabezpieczenia, które na podstawie art. $156 \S 1$ pkt 2 ustawy egzekucyjnej zawierać musi - podobnie jak tytuł wykonawczy - numer PESEL lub NIP zobowiązanego ${ }^{57}$.

\section{Orzekanie przez organ nadzoru o wstrzymaniu postępowania egzekucyjnego (czynności egzekucyjnej)}

Ustawodawca, dokonując nowelizacji ustawy egzekucyjnej, zdecydował się zmienić brzmienie art. 23 ustawy egzekucyjnej (w zakresie $\S 5,6$ i 8 tego przepisu) i tym samym ukształtować w sposób odmienny niż dotychczas działanie organu nadzoru w zakresie orzekania o wstrzymaniu czynności egzekucyjnych. Główne zmiany omawianej instytucji prawnej sprowadzają się do odsunięcia (odciążenia) Ministra Finansów od rozpoznawania zażaleń na postanowienia organu nadzoru, formy zainicjowania działań organu nadzoru w zakresie wstrzymywania postępowania egzekucyjnego (czynności egzekucyjnych) oraz katalogu podmiotów uprawnionych do zaskarżenia rozstrzygnięcia organu nadzoru.

Jak zaznaczono w uzasadnieniu projektu ustawy ${ }^{58}$, obowiązujące do dnia 1 stycznia 2016 r. brzmienie art. 23 § 6 ustawy egzekucyjnej skutkowało błędną interpretacją omawianego przepisu przez zobowiązanych, czego następstwem było mylne przekonanie, że na tej podstawie przysługują tym podmiotom dodatkowe uprawnienia procesowe ${ }^{59}$. Należy

${ }^{56}$ Dz.U. poz. 656 ze zm.

${ }^{57}$ Druk sejmowy nr 3320/VII kadencja.

${ }^{58}$ Ibidem.

${ }^{59}$ Por. wyrok NSA z 22 IV 2010 r., sygn. II FSK 472/10, Centralna Baza Orzeczeń Sądów Administracyjnych, http://orzeczenia.nsa.gov.pl/doc/787922B886 (dostęp: 17 III 2016). 
zaznaczyć, że zarówno w judykaturze ${ }^{60}$, jak i w doktrynie ${ }^{61}$ podnosi się, iż orzeczenie przez organ nadzoru w przedmiocie wstrzymania (postępowania albo czynności egzekucyjnych) następuje zawsze z urzędu, a złożony przez zobowiązanego wniosek stanowić może dla organu nadzoru jedynie podstawę do podjęcia czynności nadzorczych. Nowe brzmienie przepisu art. $23 \S 6$ ustawy egzekucyjnej w sposób jednoznaczny wskazuje, że działanie organu nadzoru następuje wyłącznie $z$ urzędu. Dopełnieniem zmiany art. $23 \S 6$ ustawy egzekucyjnej jest nowe brzmienie art. $23 \S 8$ ustawy egzekucyjnej, gdzie zaznaczono, że zażalenie na postanowienie organu nadzoru w przedmiocie wstrzymania czynności egzekucyjnych lub wstrzymania postępowania egzekucyjnego służy wyłącznie wierzycielowi niebędącemu jednocześnie organem egzekucyjnym.

Z omawianą zmianą funkcjonalnie skorelowana jest modyfikacja przepisu art. 17 ustawy egzekucyjnej poprzez dodanie do niego $\S 1 \mathrm{~b}$. Rozbudowa wskazanego przepisu prawa przejawia się w odesłaniu do uregulowania wskazanego $\mathrm{w}$ art. $127 \S 3$ k.p.a. Nowa regulacja przewiduje, że do zażaleń wydawanych w I instancji przez organ nadzoru stosuje się odpowiednio przepisy o ponownym rozpoznaniu sprawy. Oznacza to, że strona pragnąca zakwestionować rozstrzygnięcie organu I instancji wydane przez organ nadzoru uprawniona będzie do złożenia zażalenia, które jednak nie będzie cechowało się dewolutywnością. $\mathrm{W}$ takim przypadku sprawa zostanie ponownie rozpoznana przez ten sam organ. Jak wskazano w uzasadnieniu sejmowego projektu ustawy ${ }^{62}$, dokonana zmiana ma na celu poprawę funkcjonowania administracji podatkowej poprzez wyłączenie od orzekania ministra finansów w sprawach indywidualnych dotyczących administracyjnego postępowania egzekucyjnego. Omawiana zmiana ma jednak charakter porządkowy, gdyż w aktualnym stanie prawnym wprowadzona regulacja będzie dotyczyć jedynie trzech spośród 51 przypadków ${ }^{63}$ zażaleń znanych ustawie

${ }^{60}$ Por. wyroki: NSA z 8 IV 2009 r., sygn. II FSK 1925/07, Centralna Baza Orzeczeń Sądów Administracyjnych, http://orzeczenia.nsa.gov.pl/doc/F58D5625A7, oraz WSA w Warszawie z 27 IX 2007 r., sygn. III SA/Wa 3584/06, Centralna Baza Orzeczeń Sądów Administracyjnych, http://orzeczenia.nsa.gov.pl/doc/0DBEB37FAF (dostęp: 17 III 2016).

${ }^{61}$ R. Hauser, Prawo procesowe administracyjne, t. 9, Warszawa 2014, § 57, pkt IX, teza 195, dostępne także na stronie http://sip.legalis.pl (dostęp: 17 III 2016).

${ }^{62}$ Druk sejmowy nr 3320/VII kadencja.

${ }^{63}$ R. Hauser, Z. Leoński, Komentarz do art. 17, nb. 2, w: Postępowanie egzekucyjne w administracji... 
egzekucyjnej. Poza omawianym w ramach niniejszego punktu zażalenia na postanowienie o odmowie wstrzymania postępowania egzekucyjnego znajdzie ona zastosowanie w przypadku skargi biegłego skarbowego na postanowienie w przedmiocie odmowy wpisania (art. 67c $\S 4$ ustawy egzekucyjnej) oraz skreślenia z listy biegłych skarbowych (art. 67c § 11 ustawy egzekucyjnej).

W wyniku wprowadzonych zmian wyeliminowane zostały wątpliwości interpretacyjne dotyczące podmiotowych oraz przedmiotowych uwarunkowań instytucji wstrzymania postępowania egzekucyjnego (czynności egzekucyjnych). Dotychczasowe brzmienie art. 23 ustawy egzekucyjnej powodowało nadużywanie przez zobowiązanych instytucji wstrzymania w sytuacjach, gdy na innej podstawie niemożliwe było odsunięcie (zapobieżenie lub odroczenie w czasie) toczącej się egzekucji. Postępowanie zobowiązanych wynikało również z nadinterpretacji (przyjęcia zbyt szerokiego zakresu zastosowania) zwrotu nieostrego "szczególnie uzasadnione przypadki”, który w swej istocie odnosi się do sytuacji spowodowanych przyczynami niezależnymi od zobowiązanego (np. wypadek losowy, stwierdzone w przewidzianym trybie nieprawidłowości lub naruszenia prawa $\mathrm{w}$ toku postępowania egzekucyjnego $)^{64}$. Poczynione zmiany sprawia, że właściwe organy w toku czynności nadzorczych będą z urzędu orzekać w przypadkach wymagających wstrzymania postępowania egzekucyjnego (czynności egzekucyjnych). Zobowiązani natomiast nie będą traktować instytucji wstrzymania jako środka konkurencyjnego bądź alternatywnego dla zarzutów czy skargi na czynności egzekucyjne. Dodatkowo zachowana została ochrona praw wierzyciela, któremu przysługuje uprawnienie do zakwestionowania rozstrzygnięć organu nadzoru.

\section{Zmiany w sferze kosztów egzekucyjnych}

Ustawodawca zdecydował się również dokonać zmian w ustawie egzekucyjnej w pewnych jej aspektach odnoszących się do kosztów egzekucyjnych. Przeprowadzone zmiany dotyczą takich zagadnień, jak tryb orzekania o kosztach postępowania egzekucyjnego, likwidacja obciążania kosztami egzekucyjnymi pewnych grup podmiotów czy rozszerzenie katalogu wydatków egzekucyjnych.

\footnotetext{
${ }^{64}$ Por. wyrok NSA z 10 I 2014 r., sygn. II FSK 1304/13, Centralna Baza Orzeczeń Sądów Administracyjnych, http://orzeczenia.nsa.gov.pl/doc/B3A6058D45 (dostęp: 17 III 2016).
} 
Pierwsza z wymienionych zmian dotyczy sposobu informowania przez organ egzekucyjny stron postępowania o obowiązku oraz wymiarze należnych kosztów egzekucyjnych. W uzasadnieniu projektu ustawy o administracji podatkowej ${ }^{65}$ podniesiono, że zamiarem ustawodawcy jest odformalizowanie omawianego etapu postępowania poprzez wprowadzenie regulacji bazującej na zasadzie skargowości. Ustawodawca w tym celu zmienił brzmienie art. 64 c poprzez przeredagowanie $\S 7$ oraz dodanie $\S 6$ a. W zmienionym stanie prawym rozstrzygnięcie organu egzekucyjnego o kosztach egzekucyjnych przebiegać będzie dwutorowo. W pierwszej kolejności organ egzekucyjny wydaje (na wniosek strony albo z urzędu) zawiadomienie o wysokości należnych od zawiadamianego kosztów egzekucyjnych, z pouczeniem o prawie do złożenia w terminie 14 dni od daty doręczenia zawiadomienia wniosku o wydanie w tym przedmiocie postanowienia. Co ważne, w przypadku gdy obowiązek pokrycia kosztów egzekucyjnych ciąży na zobowiązanym, zawiadomienie może zostać wystosowane tylko w następstwie złożonego przez tę stronę wniosku, o którym mowa w art. 64c $\S 6$ a pkt 1 ustawy egzekucyjnej. Termin do wystąpienia z żądaniem wynosi 6 miesięcy i liczony jest od dnia wyegzekwowania należności (w przypadku egzekucji z nieruchomości - od ostateczności postanowienia o przysądzeniu własności) albo od dnia, w którym postanowienie o umorzeniu postępowania egzekucyjnego stało się ostateczne. W przypadku obciążania kosztami wierzyciela organ egzekucyjny dokonuje zawiadomienia $z$ urzędu, w terminie jednego miesiąca od dnia doręczenia ostatecznego postanowienia umarzającego postępowania egzekucyjne. Jeżeli strona postępowania obciążona kosztami egzekucyjnymi kwestionuje zasady lub sposób ich naliczenia przez organ egzekucyjny, obowiązana jest w terminie 14 dni od daty doręczenia jej zawiadomienia złożyć wniosek o wydanie postanowienia. Na postanowienie organu egzekucyjnego przysługuje zażalenie. Za aktualny również w nowym stanie prawnym należy uznać pogląd wyrażony przez Naczelny Sąd Administracyjny ${ }^{66}$, gdzie wskazano, że termin określony w art. 64c $\S 8$ ustawy egzekucyjnej „jest terminem ustawowym, zawitym, o charakterze materialnym. Bezskuteczny upływ takiego terminu, wobec braku stosownego żądania uprawnionego podmiotu (zobowiązanego), powoduje

${ }^{65}$ Druk sejmowy nr 3320/VII kadencja.

${ }^{66}$ Por. wyrok NSA z 13 VIII 2014 r., sygn. II FSK 2026/12, Centralna Baza Orzeczeń Sądów Administracyjnych, http://orzeczenia.nsa.gov.pl/doc/586321EDFE (dostęp: 25 III 2016). 
niedopuszczalność rozstrzygania kwestii kosztów egzekucyjnych, które nie obciążają wierzyciela. Termin $\mathrm{z}$ art. 64c $\S 8$ ustawy jako termin prawa materialnego nie podlega przywróceniu". Stosując model wnioskowania a minori ad maius, należy przyjąć, że materialnoprawny charakter ma też termin do złożenia przez zobowiązanego wniosku o wydanie zawiadomienia w przedmiocie kosztów egzekucyjnych.

Druga zmiana przejawia się w dodanym do art. 64c ustawy egzekucyjnej § 4d. Przepis ten stanowi, że organy będące naczelnikami urzędów skarbowych lub dyrektorami izb celnych nie obciążają się wzajemnie kosztami egzekucyjnymi oraz opłata, o której mowa w art. 64c $\S 2$ ustawy egzekucyjnej. Wprowadzona regulacja stanowi wyjątek od ustawowej zasady wyrażonej w art. 64c § 4 ustawy egzekucyjnej, na mocy której wierzyciel pokrywa koszty egzekucyjne nieściągnięte w toku egzekucji od zobowiązanego. Dokonana zmiana legislacyjna zrównuje zatem wierzycieli będących naczelnikami urzędów skarbowych lub dyrektorów izb celnych w prawach $\mathrm{z}$ wierzycielami prowadzącymi egzekucję na podstawie jednolitego tytułu wykonawczego lub zagranicznego tytułu wykonawczego w zakresie finansowej odpowiedzialności za wynik nieskutecznej egzekucji ${ }^{67}$. W uzasadnieniu projektu ustawy ${ }^{68}$ zaakcentowano, że niepragmatyczne jest wzajemne obciążanie się podmiotów funkcjonujących w ramach tej samej jednostki budżetowej (naczelnicy urzędów skarbowych), a także wchodzących w skład jednego resortu Ministerstwa Finansów (dyrektorzy izb celnych).

Przyjąć trzeba, iż przeprowadzona zmiana wpłynie pozytywnie na ekonomikę postępowania, gdyż uwolni organy egzekucyjne od obowiązku rozpoznawania wniosków - uprzednio nieuprzywilejowanych wierzycieli - o umorzenie kosztów na podstawie art. 64e § 2 pkt 2. Warto dodać, że przed wprowadzeniem zmian naczelnicy urzędów skarbowych (działający jako organy egzekucyjne) po otrzymaniu wniosku innego naczelnika urzędu skarbowego (występującego jako wierzyciel) wydawali postanowienia o umorzeniu kosztów egzekucyjnych na rzecz tych podmiotów, co wynikało z wewnętrznych wytycznych resortu finansów. W chwili obecnej przeprowadzanie postępowania w przedmiocie obciążania kosztami egzekucyjnymi w wewnętrznej relacji podmiotów wskazanych $\mathrm{w}$ art. $64 \mathrm{c} \S 4 \mathrm{~d}$ ustawy egzekucyjnej stało się zbędne.

${ }^{67}$ Mowa tu o egzekucji, w której nie uzyskano sum wystarczających na pokrycie kosztów egzekucyjnych.

${ }^{68}$ Druk sejmowy nr 3320/VII kadencja. 
Ostatnim novum w zakresie kosztów egzekucyjnych jest poszerzenie katalogu wydatków egzekucyjnych, wyrażone w art. 64b ustawy egzekucyjnej. Ustawodawca zdecydował przeredagować omawiany przepis i dodać do niego § 2, który stanowi, że wydatkiem egzekucyjnym jest również koszt przekazania wierzycielowi kwot wyegzekwowanych na podstawie jednolitego tytułu wykonawczego lub zagranicznego tytułu wykonawczego. W uzasadnieniu sejmowego projektu ustawy ${ }^{69}$ wskazano, że dotychczas koszty prowizji bankowych obciążały organ egzekucyjny jako koszty udzielenia wzajemnej pomocy w myśl ustawy o wzajemnej pomocy i na mocy regulacji wspólnotowych nie mogły być nimi obciążane państwa wnioskujące o udzielenie tej pomocy.

Wskazaną zmianę należy ocenić pozytywnie, bowiem wszelkie koszty związane z prowadzeniem egzekucji powinny obciążać zobowiązanego jako podmiot, który poprzez niewykonanie obowiązku przyczynił się do jej wszczęcia. Jednakże funkcjonujący do dnia 31 grudnia 2015 r. katalog wydatków egzekucyjnych poprzez użycie formuły enumeracji niezupełnej (poprzez zastosowanie sformułowania „w szczególności”) umożliwiał zaliczenie kosztów przekazania wyegzekwowanych kwot do państwa członkowskiego lub państwa trzeciego, gdyż były to koszty faktycznie poniesione przez organ egzekucyjny w związku z prowadzeniem egzekucji. Dokonana zmiana powoduje jednak, że wskazana materia nie stanowi już sfery uznania organu prowadzącego postępowanie, ale została wprost określona w przepisie prawa. Tym samym w nowym stanie prawnym kwestionowanie przez zobowiązanego naliczenia wydatku egzekucyjnego z tytułu przekazania środków pieniężnych do państwa członkowskiego lub państwa trzeciego stanie się całkowicie bezskuteczne.

\section{Pozostałe zmiany ustawy}

Poza zmianami ustawy egzekucyjnej opisanymi szerzej na łamach przedłożonego projektu ustawodawca wprowadził jeszcze inne zmiany o charakterze wyłącznie technicznym czy redakcyjnym.

Pierwsza ze zmian dotyczy art. $5 \S 1$ pkt 5 ustawy egzekucyjnej i polega na udzieleniu kompetencji naczelnikom urzędów skarbowych do wykonywania obowiązków związanych z podjęciem czynności zmierzających do zastosowania środków egzekucyjnych w odniesieniu do

\footnotetext{
${ }^{69}$ Ibidem.
} 
grzywien nałożonych w drodze mandatu karnego i stanowiących dochód budżetu państwa ( $\mathrm{z}$ wyłączeniem grzywien nakładanych przez organy Inspekcji Transportu Drogowego). W praktyce jednak przepis art. $5 \S 1$ pkt 5 ustawy egzekucyjnej jest sprzężony z art. $100 \S 13$ Kodeksu postępowania w sprawach o wykroczenia ${ }^{70}$ oraz wydanym na jego podstawie Rozporządzeniem Ministra Finansów z dnia 13 listopada 2015 r. w sprawie właściwości miejscowej naczelnika urzędu skarbowego uprawnionego do poboru należności wynikających $\mathrm{z}$ grzywien nałożonych $\mathrm{w}$ drodze mandatu karnego ${ }^{71}$, który ustanawia właściwym dla wszystkich spraw tego rodzaju Naczelnika Pierwszego Urzędu Skarbowego w Opolu. Tym samym na mocy art. 75 ustawy o administracji podatkowej w zw. $\mathrm{z}$ art. 1 ust. 2 lit. b ustawy o zmianie ustawy o administracji podatkowej dla grzywien nałożonych w drodze mandatu karnego od dnia 1 stycznia 2016 r. organami właściwymi do wykonywania funkcji wierzyciela przestają być wojewodowie, a staje się nim Naczelnik Pierwszego Urzędu Skarbowego w Opolu.

Druga zmiana dotyczy nowelizacji art. $163 \S 2$ ustawy egzekucyjnej i odnosi się do trybu obciążania wierzyciela kosztami postępowania zabezpieczającego. $\mathrm{W}$ tym przedmiocie odpowiednie zastosowanie znajdą zmodyfikowane przepisy art. 64c § 6a pkt 2 i $\S 7$ ustawy egzekucyjnej, które zostały szczegółowo scharakteryzowane w punkcie ósmym niniejszego opracowania.

Ostatnia ze zmian związana jest $\mathrm{z}$ wydłużeniem terminu do rozpoznania przez organ II instancji odwołania od postanowienia organu egzekucyjnego w przedmiocie zgłoszonych zarzutów. Znowelizowana wersja art. 34 § 5 ustawy egzekucyjnej nie przewiduje już specjalnego 14-dniowego terminu na rozpoznanie tego typu zażaleń. Dlatego też od dnia 1 stycznia 2016 r. na podstawie art. 18 ustawy egzekucyjnej odpowiednie zastosowanie znajdzie dyspozycja wyrażona $w$ art. $35 \S 3$ k.p.a., która ustanawia termin jednomiesięczny na przeprowadzenie postępowania odwoławczego.

\section{Podsumowanie}

Przedłożone opracowanie analizuje wieloaspektowość zmian, jakie dokonały się w ustawie egzekucyjnej. Bez wątpienia dokładniejsza ich ocena będzie możliwa dopiero po dłuższym okresie obowiązywania

\footnotetext{
70 Tekst jedn. Dz.U. 2013, poz. 395 ze zm.

${ }^{71}$ Dz.U. poz. 1977.
} 
ustawy, kiedy to interpretacja nowych przepisów wzbogacona zostanie o nadbudowę w postaci orzeczeń sądów administracyjnych oraz poglądów doktryny. Jednak już w tym momencie można stwierdzić, że zamiarem ustawodawcy było usprawnienie administracyjnego postępowania egzekucyjnego, a także jego odformalizowanie i wprowadzenie pewnych elementów kontradyktoryjnych. Widać to szczególnie w poczynieniu pewnych odstępstw od nieprzewidującej dotychczas wyjątków zasady prawnego obowiązku prowadzenia egzekucji. Ustawodawca zdecydował się również wnieść do procedury egzekucyjnej pewne elementy skargowe, związane z wydawaniem określonych typów orzeczeń wyłącznie na wniosek strony. Poczynione zmiany wpływają pozytywnie na ekonomikę postępowania przy jednoczesnym zagwarantowaniu istniejących dotychczas praw stron. Postulat szybkości postępowania ma być realizowany również poprzez rozszerzenie zakresu orzecznictwa będącego w gestii organu egzekucyjnego oraz zrezygnowanie $z$ rozpoznawania spraw indywidualnych przez naczelny organ administracji rządowej - ministra finansów. Ponadto odstąiono od wzajemnego obciążania się kosztami pomiędzy podmiotami podległymi temu samemu ministrowi. Za istotne należy uznać także poszerzenie kompetencji organu egzekucyjnego w zakresie uprawnienia informacyjnego w stosunku do instytucji finansowych, zwłaszcza banków. Warto również odnotować wprowadzenie obowiązku zamieszczania w tytule wykonawczym identyfikatorów NIP lub PESEL dotyczących osoby zobowiązanego.

Reasumując, wprowadzone zmiany ujawniają cele państwa w zakresie przymusowego wykonywania obowiązków publicznoprawnych. $\mathrm{W}$ założeniu ustawodawcy działania podejmowane przez wierzycieli oraz organy egzekucyjne powinny być nakierowane na efektywne prowadzenie postępowań i mają skutkować zwiększeniem wpływów uzyskiwanych w trybie egzekucji administracyjnej.

\section{THE LATEST AMENDMENTS \\ TO THE LAW ON ADMINISTRATIVE PROCEEDINGS}

\section{Sum mary}

The Act on Administrative Enforcement Proceedings was adopted on 17 June 1966. The Act constitutes the basis of enforcement proceedings in administration and has been in force for the last fifty years. Despite many political and socio-economic changes during that period, the national legislature decided not to introduce any 
new legislation but simply modify the existing regulations. This study aims to describe and explain the amendments to the law on administrative proceedings which came into force on 1 January 2016. These amendments are connected with the solutions worked out in the model structures of tax administration organisations resulting from the enactment of the Act on Tax Administration of 10 July 2015 and require extensive discussion as they change the essential components of the procedure i.e. initiation of enforcement proceedings by creditors, exclusion of the Minister of Finance from the jurisdiction in the second instance in individual cases of enforcement procedure, the possibility of authorising local governments own organisational units to exercise the rights and obligations of the creditor and the enforcement authority, postponement of enforcement proceedings or enforcement actions, mandatory elements of an administrative enforcement title, the procedure adopted by an enforcement authority at the stage of examining the admissibility of an enforcement order, information rights of the enforcement authority, recognition of complaints regarding enforcement actions (general and connected with applying a specific enforcement measure) as well as the excessive length of proceedings and elimination of enforcement costs if creditors are tax offices or customs chambers.

Keywords: administrative enforcement - administrative enforcement proceedings amendments to the law on administrative proceedings 